\title{
-Original-
}

\section{Effect of Mouse Strain in a Model of Chemical- induced Respiratory Allergy}

\author{
Risako NISHINO, Tomoki FUKUYAMA, Yuko WATANABE, Yoshimi KUROSAWA, Hideo UEDA, \\ and Tadashi KOSAKA
}

The Institute of Environmental Toxicology, Uchimoriya-machi 4321, Joso-shi, Ibaraki 303-0043, Japan

\begin{abstract}
The inhalation of many types of chemicals is a leading cause of allergic respiratory diseases, and effective protocols are needed for the detection of environmental chemical-related respiratory allergies. In our previous studies, we developed a method for detecting environmental chemicalrelated respiratory allergens by using a long-term sensitization-challenge protocol involving BALB/C mice. In the current study, we sought to improve our model by characterizing strain-associated differences in respiratory allergic reactions to the well-known chemical respiratory allergen glutaraldehyde (GA). According to our protocol, BALB/c, NC/Nga, C3H/HeN, C57BL/6N, and CBA/J mice were sensitized dermally with GA for 3 weeks and then challenged with intratracheal or inhaled $\mathrm{GA}$ at 2 weeks after the last sensitization. The day after the final challenge, all mice were euthanized, and total serum IgE levels were assayed. In addition, immunocyte counts, cytokine production, and chemokine levels in the hilar lymph nodes (LNs) and bronchoalveolar lavage fluids (BALF) were also assessed. In conclusion, BALB/C and NC/Nga mice demonstrated markedly increased IgE reactions. Inflammatory cell counts in BALF were increased in the treated groups of all strains, especially $\mathrm{BALB} / \mathrm{c}, \mathrm{NC} / \mathrm{Nga}$, and $\mathrm{CBA} / \mathrm{J}$ strains. Cytokine levels in LNs were increased in all treated groups except for $\mathrm{C} 3 \mathrm{H} / \mathrm{HeN}$ and were particularly high in BALB/c and NC/Nga mice. According to our results, we suggest that $\mathrm{BALB} / \mathrm{C}$ and $\mathrm{NC} / \mathrm{Nga}$ are highly susceptible to respiratory allergic responses and therefore are good candidates for use in our model for detecting environmental chemical respiratory allergens.
\end{abstract}

Key words: glutaraldehyde, repiratory allergy, strain difference

\section{Introduction}

Many new chemical substances are produced every day, and chemical-induced allergy has emerged as a public health problem worldwide $[3,15]$. In particular, the inhalation of many types of chemicals (allergens and irritants) is a leading cause of respiratory diseases $[8,19,25]$. Furthermore, the compounds associated with fine particulate matter (that is, PM2.5; $<2.5 \mu$ m aerodynamic diameter) aggravate respiratory responses to common allergens $[13,18]$. Therefore, there is an urgent need to develop an effective method to identify chemicalinduced respiratory allergens [38]. Traditionally, several in vitro and in vivo detection methods involving various animal species, strains, cell types, and exposure pathways have been used to identify chemical-induced respiratory allergy $[4,22,34]$, but none of these methods have proven to be sufficiently sensitive.

Previously, in the first phase of our studies, we developed a method for detecting environmental chemicalrelated respiratory allergens. Specifically we used typical chemical sensitizers (i.e., 2,4-dinitrochlorobenzene

(Received 28 February 2014 / Accepted 21 May 2014 / Published online in J-STAGE 22 July 2014)

Address correspondence: Dr. T. Fukuyama, Laboratory of Immunotoxicology and Acute Toxicology, Toxicology Division, The Institute of Environmental Toxicology, Uchimoriya-machi 4321, Joso-shi, Ibaraki 303-0043, Japan

(C)2014 Japanese Association for Laboratory Animal Science 
[DNCB], trimellitic anhydride, and toluene diisocyanate) in a long-term dermal sensitization protocol followed by intratracheal respiratory challenge of mice [11, 12]. DNCB is a contact allergen, whereas trimellitic anhydride and toluene diisocyanate are respiratory allergens. In our system, the respiratory allergens induced prominent increases in several parameters indicative of induced allergic response, including IgE levels, eosinophilic proliferation, and elevated local (lung airway) chemokine (MCP-1, MIP-1 $\beta$, and eotaxin) and cytokine (interleukin [IL]-4, -10, and -13) levels. In contrast, DNCB sensitization yielded only non-significant increases in each of these parameters. These results demonstrated that our method can be applied to detect and classify allergic reactions caused by chemicals present in the environment at weakly immunogenic and low doses. However, susceptibilities to environmental chemical allergens may differ between animal species, strains, and exposure routes [29, 43].

In the current work, our second phase of studies, we sought to improve our detection protocol by focusing attention on mouse-strain-associated differences in respiratory allergic reactions. Specifically we evaluated the BALB/c, NC/Nga, C3H/HeN, C57BL/6N, and CBA/J strains of mice, which are often used in allergy models, and the chemical respiratory allergen glutaraldehyde (GA). GA is widely used in the industrial, scientific, and biomedical fields. For example, GA is the best disinfectant available for cold sterilization of medical equipment. However, GA is irritating to the skin and respiratory tract and highly volatile at ambient temperature [2, 42]. These factors contribute to the prevalence of chronic bronchitis and nasal symptoms in humans [37], and numerous cases of occupational asthma resulting from GA exposure have been reported [33]. In addition, GA has often been used in the development of chemical-induced respiratory allergy models in mice [40].

\section{Method}

\section{Animals}

Female inbred C57BL/6N, BALB/c, CBA/J, NC/Nga, and $\mathrm{C} 3 \mathrm{H} / \mathrm{HeN}$ mice (age, 7 weeks) were purchased from Charles River Japan (Atsugi, Kanagawa, Japan) and acclimated for 6 days before the start of the experiment. Mice were housed individually under controlled lighting (lights on from 7:00 to 19:00 h), temperature $\left(22 \pm 3^{\circ} \mathrm{C}\right)$, humidity $(50 \% \pm 20 \%)$, and ventilation (at least 10 com- plete fresh-air changes hourly). Food (Certified Pellet Diet MF, Oriental Yeast, Tokyo, Japan) and water were available ad libitum. The current study was conducted in accordance with the Animal Care and Use Program of the Institute of Environmental Toxicology (IET IACUC Approval No. AC12095).

Female mice were selected as the model for this study because the OECD Skin Sensitization Guideline for the Testing of Chemicals [31] recommend for using female mice. Furthermore, in immunotoxicity studies, only one gender need be evaluated; in general, females are considered to yield more consistent outcomes than male animals when evaluating humoral immune responses.

\section{Chemicals}

Glutaraldehyde $\left(\mathrm{GA}, \mathrm{C}_{5} \mathrm{H}_{8} \mathrm{O}_{2}, 50 \%\right)$ was purchased from Kanto Chemical Co., Inc. (Tokyo, Japan). Acetone and olive oil were purchased from Wako Pure Chemical Industries (Osaka, Japan). For dermal sensitization, GA was dissolved in acetone: olive oil $(4: 1)$ to $0.5 \%(\mathrm{w} / \mathrm{v})$. For inhalation sensitization and challenge, GA was dissolved in phosphate-buffered saline (PBS). For intratracheal challenge, GA was dissolved in PBS.

\section{Local lymph node assay (LLNA)}

We conducted an LLNA as a preliminary test to select the concentrations of GA to use in the main studies. The assay was performed as described by Kimber and Weisenberger [20] and in the OECD Guideline for the Testing of Chemicals [31], with minor modifications. $\mathrm{CBA} / \mathrm{J}$ mouse is a recommended species used for the Local Lymph Node Assay. After a 1-week acclimation period, $\mathrm{CBA} / \mathrm{J}$ mice were allocated randomly to dose and control groups ( $\mathrm{n}=3$ per group). A $25-\mu 1$ aliquot of test solution or solvent only was applied daily to the dorsum of each ear of each mouse for 3 consecutive days (days 1 through 3). On day $6,{ }^{3} \mathrm{H}$-methyl thymidine $\left({ }^{3} \mathrm{H}\right.$ TdR, $20 \mu \mathrm{Ci} /$ animal; specific radioactivity, $1 \mathrm{mCi} / \mathrm{ml}$; PerkinElmer Japan Co., Ltd.., Kanagawa, Japan) was injected via the tail vein into all test and control mice; at $5 \mathrm{~h}$ after injection, the mice were euthanized by exsanguination from the abdominal aorta and posterior vena cava under the intraperitoneal injection of pentobarbital sodium $(75 \mathrm{mg} / \mathrm{kg})$, and the auricular LNs on both sides of each mouse were removed, weighed, and pooled by mouse in PBS (Life Technologies Co., Ltd.., USA). Single-cell suspensions of LNs in $5 \mathrm{ml}$ PBS were prepared by passage through sterile $70-\mu$ m nylon cell 
: Sensitization by dermal exposure with GA

: Challenge by inhalation exposure with GA

$A$ : Challenge by intratracheal exposure with GA

\begin{tabular}{|c|c|c|c|c|}
\hline 8 weeks & 9 weeks & 10 weeks & 11 weeks & 12 weeks \\
\hline
\end{tabular}

Days 1 - 3

8 - 10

$15-17$

$29-31$

Sacrific

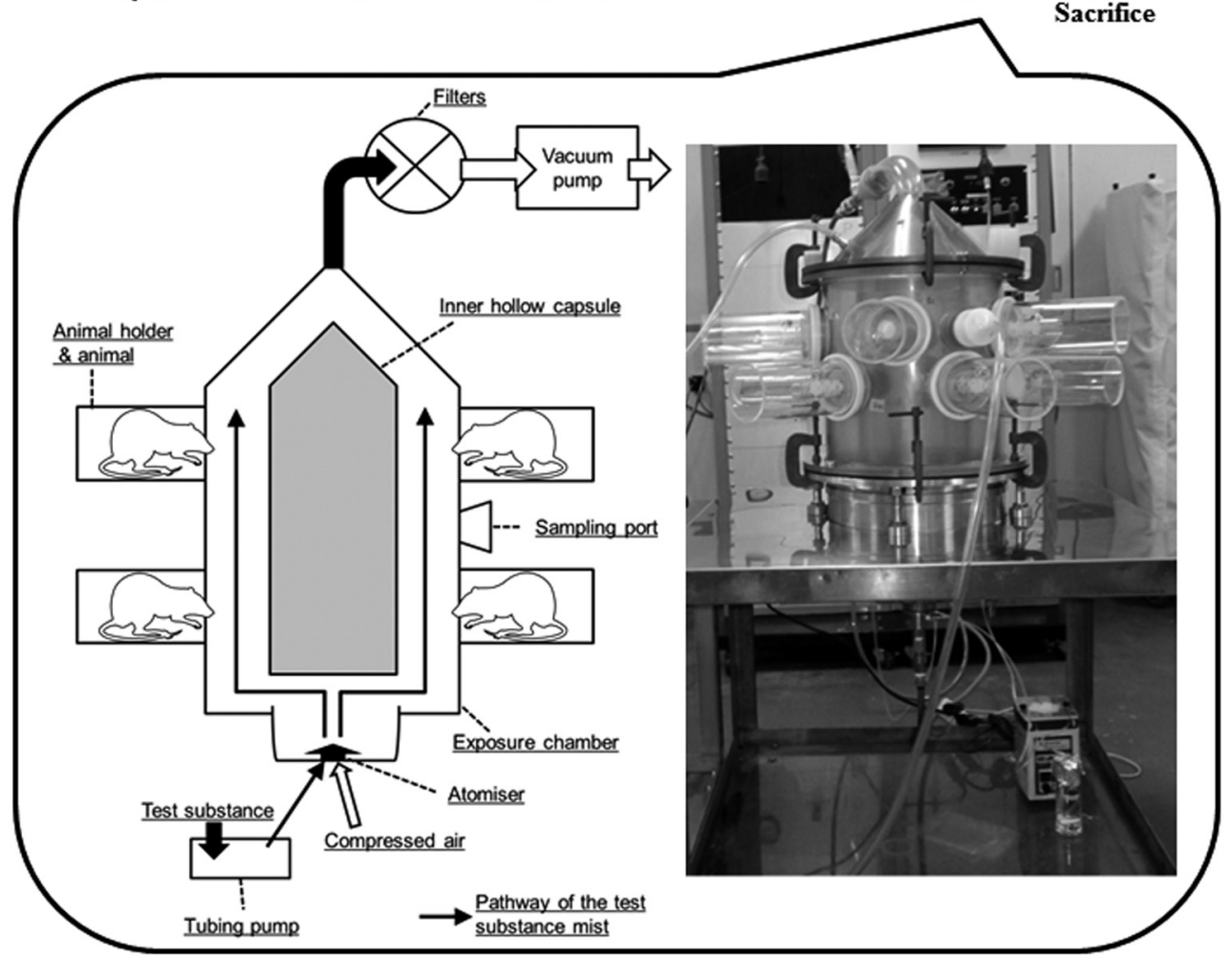

Fig. 1. Experimental protocol and apparatus for inhalation exposure. See Materials and Methods for a detailed description.

strainers (Falcon, Tokyo, Japan). The LN cell suspension was washed twice with an excess of PBS, and the cell pellet was incubated in $3 \mathrm{ml} \mathrm{5 \%}$ trichloroacetic acid (TCA, Wako Pure Chemical Industries, Ltd.) at $4{ }^{\circ} \mathrm{C}$ for approximately $18 \mathrm{~h}$. Each cell pellet was resuspended in $1 \mathrm{ml}$ TCA and transferred to $9 \mathrm{ml}$ of scintillation fluid (PICO-FLUOR PLUS, PerkinElmer Japan Co., Ltd.). For each mouse, incorporation of ${ }^{3} \mathrm{H}-\mathrm{TdR}$ was measured as disintegrations per min (DPM) by using a $\beta$-scintillation counter (LC-5100, Aloka, Tokyo, Japan).

Stimulation indexes (SIs) and EC3 values were calculated from the ${ }^{3} \mathrm{H}-\mathrm{TdR}$ incorporation data. The SI was calculated by dividing the mean ${ }^{3} \mathrm{H}-\mathrm{TdR}$ incorporation value for each treatment group by that of the solvent control group. The EC3 value is an estimate of the amount of test solution required to induce an SI of 3 [5].
In the standard LLNA, the criterion for a positive response is an SI of 3 or greater [9, 31].

\section{Experimental protocol}

The experimental protocol we used in this study is depicted in Fig. 1. After a 6-day acclimation period, we randomly allocated $\mathrm{C} 57 \mathrm{BL} / 6 \mathrm{~N}, \mathrm{BALB} / \mathrm{c}, \mathrm{CBA} / \mathrm{J}, \mathrm{NC} /$ $\mathrm{Nga}$, and $\mathrm{C} 3 \mathrm{H} / \mathrm{HeN}$ mice (age, 8 weeks) to groups ( $n=5$ mice per group) for dosing or no treatment (control). Because our preliminary study revealed that mice sensitized or challenged with GA only showed much the same pattern of allergic airway inflammatory responses, as did the intact group, data from similar groups in the current study are not shown.

For sensitization, $0.5 \%$ of GA was applied dermally to both ears ( $25 \mu \mathrm{l} / \mathrm{ear} ; 50 \mu \mathrm{l} / \mathrm{animal})$ of each mouse on 
days 1 through 3,8 through 10 , and 15 through 17 . Two weeks after the last sensitization, each mouse was challenged with $50 \mu \mathrm{l}$ of $0.05 \%$ GA intratracheally on day 31 or with $0.25 \%$ GA by inhalation for $1 \mathrm{~h}$ on days 29 through 31 . These doses were based on the EC3 concentration determined in our preliminary LLNAs. One day after the last challenge, all mice (control and treated) were euthanized by exsanguination from the abdominal aorta and posterior vena cava under the intraperitoneal injection of pentobarbital sodium $(75 \mathrm{mg} / \mathrm{kg})$. Blood samples were taken from the inferior vena cava, and serum samples were assayed for total $\operatorname{IgE}$ levels. Bronchoalveolar lavage fluid (BALF) was collected by cannulating the trachea and lavaging the lungs 3 times each with $1 \mathrm{ml}$ PBS supplemented with $1 \%$ heat-inactivated fetal calf serum (FCS; Life Technologies Co., Ltd.., Tokyo, Japan). The first BALF fraction from each animal was centrifuged at $350 \times \mathrm{g}$ for $5 \mathrm{~min}$, these supernatants were pooled respectively, and chemokine levels were measured. The cell pellets of all three fractions per mouse were resuspended, pooled by mouse, and centrifuged at $350 \times g$ for $5 \mathrm{~min}$. The supernatants were removed, and the cell pellets were used for differential cell counts. Hilar lymph nodes (LNs) from each mouse were pooled in RPMI 1640 medium (Life Technologies Co., Ltd., USA). Single-cell suspensions were prepared from LNs by passage through a sterile $70-\mu \mathrm{m}$ nylon cell strainer in $1 \mathrm{ml}$ RPMI 1640 supplemented with 5\% FCS. Single-cell suspensions were used to analyze the IgE-positive B-cell counts and cytokine production.

\section{Intratracheal injection}

Two weeks after the last sensitization, mice were anesthetized by intraperitoneal injection of pentobarbital sodium $(25 \mathrm{mg} / \mathrm{kg})$, and an challenge with a $50-\mu 1$ aliquot of $0.05 \% \mathrm{GA}$ in saline solution was injected into intratracheal using a $29-\mathrm{G}$ needle.

\section{Inhalation exposure}

For the inhaled challenge, mice were exposed to $0.25 \%$ GA in PBS mist continuously for $1 \mathrm{~h}$ daily $(0.0125 \mathrm{mg} / \mathrm{l})$. The placement of mice in the chamber is shown in Fig. 1. Mice were restrained individually in animal holders (Tokiwa Kagakukikai Co., Ltd., Tokyo, Japan) attached to a nose-only exposure chamber (total volume, 31.2 1; Tokiwa Kagakukikai Co., Ltd.) so that only their noses were exposed to the chemical mist. The mist was generated by an atomizer (Ikeuchi Co., Ltd., Tokyo, Japan) using compressed air (ES4AD-5, Kobelco, Tokyo, Japan) and was supplied to the exposure chamber through an air filter (F3000-10-Y, CKD Corporation, Aichi, Japan). Airflow to the chamber was controlled at a rate of $20 \mathrm{l} / \mathrm{min}$ by using an area flowmeter (NSPO-4, Nippon Flow Cell, Tokyo, Japan). The chamber air was exhausted through an air filter system consisting of a glass wool filter, a mist trap, and an activated charcoal filter (Tokiwa Kagakukikai Co., Ltd.) and was emitted to the atmosphere by using a blower (TFO-K4P, Hitachi, Ltd., Tokyo, Japan). The actual concentration, mass median aerodynamic diameter (MMAD), and geometric standard deviation (GSD) were monitored by gravimetric analysis by using an air sampler (MF-200, Oct Science Co., Ltd., Osaka, Japan) and a mist sampler (MC-500 sampler, Tokyo Dylec Corp.). The mean values of MMAD and GSD were kept at approximately $4.0 \mu \mathrm{m}$ and 2.0, respectively, throughout inhalation exposure.

\section{Total $\lg E$}

Total IgE levels in serum were measured by enzymelinked immunosorbent assay (BD OptEIA Mouse IgE ELISA Set, BD Pharmingen, Tokyo, Japan) according to the manufacturer's protocol.

\section{Flow cytometry of BALF and hilar LN cells}

The following antibodies used for flow cytometric analysis were purchased from BD Pharmingen: fluorescein isothiocyanate (FITC)-conjugated anti-mouse IgE (clone R35-72), phycoerythrin (PE)-conjugated hamster anti-mouse CD11c (HL3), FITC-conjugated anti-mouse Gr-1 (RB6-8C5), and allo-phycocyanin-conjugated antimouse CD45R/B220 (RA3-6B2). To avoid nonspecific binding, $1 \times 10^{6}$ cells were incubated with $1 \mu \mathrm{g}$ Mouse BD Fc Block (BD Pharmingen) for $5 \mathrm{~min}$ at $4^{\circ} \mathrm{C}$, followed by incubation with monoclonal antibodies for 30 $\min$ at $4^{\circ} \mathrm{C}$ in the dark. Cells were washed twice with $5 \%$ FCS in PBS, resuspended at $1 \times 10^{6}$ cells per tube in $500 \mu \mathrm{l}$ PBS, and analyzed on a FACSVerse flow cytometer (BD Pharmingen) by using the FACSuite program (BD Pharmingen). To analyse antigen expression, 5000 and 20,000 events were collected from BALF and LN samples, respectively.

\section{Chemokine levels in BALF}

The levels of the chemokines MIP-1 $\beta$ and RANTES were measured by using a cytometric bead array (BD 
CBA Mouse Flex Set, BD Pharmingen) according to the manufacturer's protocol.

\section{Cytokine production from helper T-cells}

CD4 positive T-cells (CD4 ${ }^{+} \mathrm{T}$-cells) were isolated from hilar LN cells $\left(1 \times 10^{7}\right.$ cells $)$ by using autoMACS (Miltenyi Biotec K.K., Tokyo, Japan) and CD4 microbeads (Miltenyi Biotec K. K) according to the manufacturer's protocol. To stimulate T-cell receptor signalling, we cultured $\mathrm{CD}^{+}$T-cells $\left(1 \times 10^{6}\right.$ cells/well $)$ for 24 or $96 \mathrm{~h}$ with Dynabeads Mouse T-Activator CD3/CD28 (25 $\mu \mathrm{g} /$ well) antibodies (Life Technologies Co., Ltd., Tokyo, Japan) in 24 -well plates at $37^{\circ} \mathrm{C}$ in a $5 \% \mathrm{CO}_{2}$ atmosphere. The levels of interferon (IFN)- $\gamma$ and IL-4, -13 , and $-17 \mathrm{~A}$ in supernatants (cell culture medium) were measured by using a cytometric bead array (BD CBA Mouse Flex Set, BD Pharmingen) according to the manufacturer's protocol.

\section{Statistical analysis}

The statistical significance of differences between the control and treatment groups was determined by using a Student's $t$-test. For each test, $P$ values less than 0.05 were considered significant.

\section{Results}

\section{LLNA}

To confirm the sensitizing potential of GA, we performed an LLNA in CBA/J mice as a preliminary test (Fig. 2). When $0.1,0.25$, or $0.5 \%$ of GA dissolved in acetone:olive oil was used, both LN weight and the incorporation of ${ }^{3} \mathrm{H}-\mathrm{TdR}$ increased dose-dependently, and SI values were 1.8, 3.0, and 9.8 times those of the vehicle-control group, respectively. According to the standard criterion for a positive response ( $\mathrm{SI} \geq 3$; Dearman et al. [9]), GA at $0.5 \%$ was confirmed to be a sensitizing agent.

\section{IgE responses}

To assess the IgE responses, we measured the total IgE levels in serum and the number of IgE-positive Bcells in the hilar LNs (Fig. 3).

The inhalation (IH) challenge group of NC/Nga mice revealed significantly increased total serum IgE levels (5.69 $[P<0.01]$ times) compared with those of the respective control group. Treatment groups in other mouse strains showed modest nonsignificant increases.
The number of IgE-positive B-cells of the IT challenge groups of all strains and $\mathrm{IH}$ challenge groups of $\mathrm{C} 3 \mathrm{H} /$ $\mathrm{HeN}$ and CBA/J tended to be increased, albeit nonsignificantly. In IH challenge groups of $\mathrm{NC} / \mathrm{Nga}$ and C57BL/6N, IgE-positive B-cell counts were increased 17.54 times $(P<0.05)$ and 8.12 times $(P<0.05)$ compared with the respective control group.

\section{BALF analysis}

To assess allergic airway inflammation in the lung, we obtained the eosinophil and neutrophil counts and levels of the chemokine such as MIP- $1 \beta$ and RANTES in BALF (Figs. 4 and 5).

Eosinophil counts were increased $(P<0.05)$ in the IT challenge groups of $\mathrm{C} 57 \mathrm{BL} / 6 \mathrm{~N}$ and in the $\mathrm{IH}$ challenge group of BALB/c mice (2.49, and 1.72 times, respectively) compared with those of the respective control group. And those in NC/Nga IT challenge group tended to be increased, although not significantly. In contrast, the eosinophil counts of both $\mathrm{C} 3 \mathrm{H} / \mathrm{HeN}$ challenge groups were comparable to those of the control groups. Neutrophil counts of all strains IT challenge groups were tended to be increased; those in BALB/c, NC/Nga, and CBA/J mice $(91.55,96.64$, and 82.49 times, respectively) were particularly high. Neutrophil counts in the IH challenge groups of all strains were similar to those of the respective control group.

The levels of MIP- $1 \beta$ have a tendency to increase in the IT challenge groups of all strains, especially those of $\mathrm{C} 57 \mathrm{BL} / 6 \mathrm{~N}$ and $\mathrm{CBA} / \mathrm{J}$ being significantly high $(P<0.05,1.59$ times and 32.18 times that of the respective control group). Compared with controls, the levels of RANTES also have a tendency to increase in all IT challenge groups, particularly those in the $\mathrm{CBA} / \mathrm{J}$ strain was significantly increased $(P<0.05)$.

\section{Analysis of hilar LNS}

We measured the production of several allergy-related cytokines (IFN- $\gamma$ and IL-4, -13, -17A) to assess the allergic reaction in the local (hilar) LNs (Fig. 6).

Compared with that in the respective control mice, IFN- $\gamma$ concentration in the hilar LNs tended to be increased in IT and IH challenge groups except for $\mathrm{C} 57 \mathrm{BL} / 6 \mathrm{~N}$, and was significantly increased in the IT challenge groups of BALB/c (2.51 times) and CBA/J (11.21 times) mice and the $\mathrm{IH}$ challenge group of $\mathrm{NC} /$ Nga mice (3.48 times). The hilar LN levels of IL-4, -13, and $17 \mathrm{~A}$ tended to be increased in IT and IH challenge 
a)
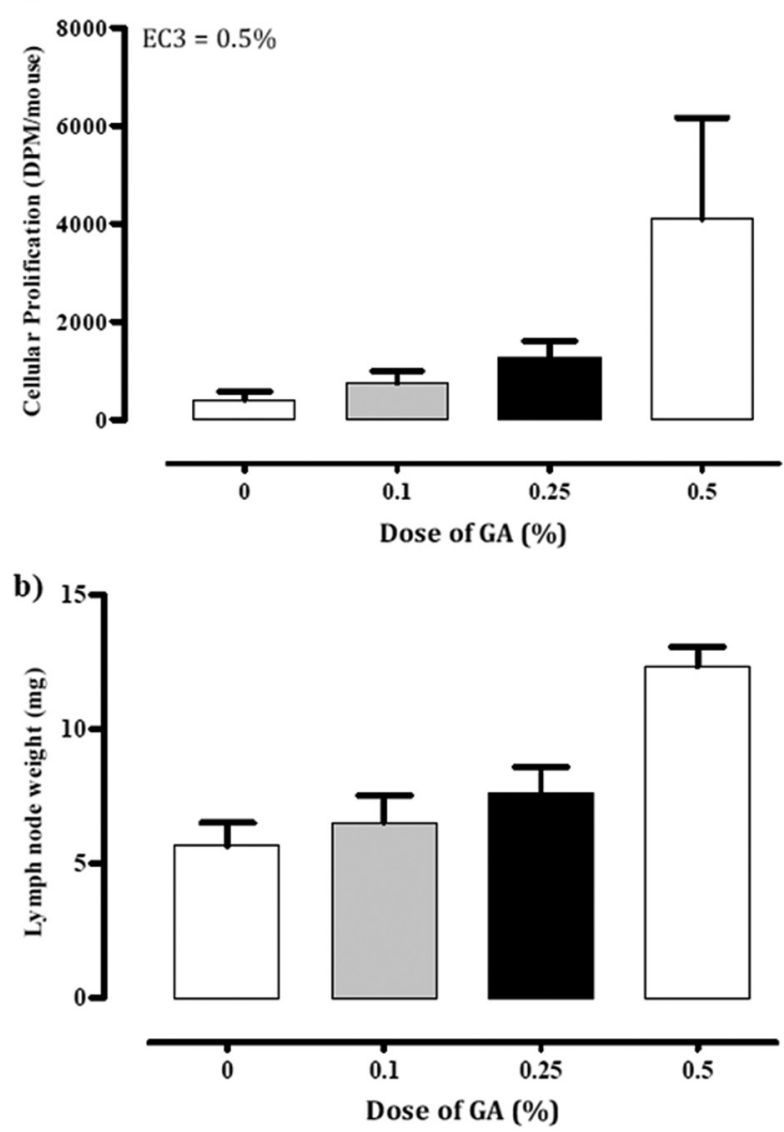

Fig. 2. (a) Cellular prolification in LLNA (mean $\pm 1 \mathrm{SD} ; n=3$ per group) (b) Lymph node weitht (mg; mean $\pm 1 \mathrm{SD} ; \mathrm{n}=3$ per group) in mice with no treatment $(0 \%)$ and treatment GA $(0.1,0.25,0.5 \%)$.

groups except for $\mathrm{C} 3 \mathrm{H} / \mathrm{HeN}$. In addition, level of IL-17A in the NC/Nga IH challenge group was 2.37 times higher than that in the control group, and those of IL-4 and -17A in C57BL/6N mice of the IH challenge group were higher than that of the respective control group (2.95 and 2.53 times, respectively). In contrast, the control group of $\mathrm{C} 3 \mathrm{H} / \mathrm{HeN}$ was notably high levels in allergy-related cytokine levels, and these cytokine levels were no increases those treated groups of $\mathrm{C} 3 \mathrm{H} / \mathrm{HeN}$.

\section{Discussion}

In a new method for detecting environmental chemical-related respiratory allergens, we initially and successfully used our novel long-term sensitization-challenge protocol in BALB/c mice $[11,12]$, one of the most popular species and strains used in allergy models and a)

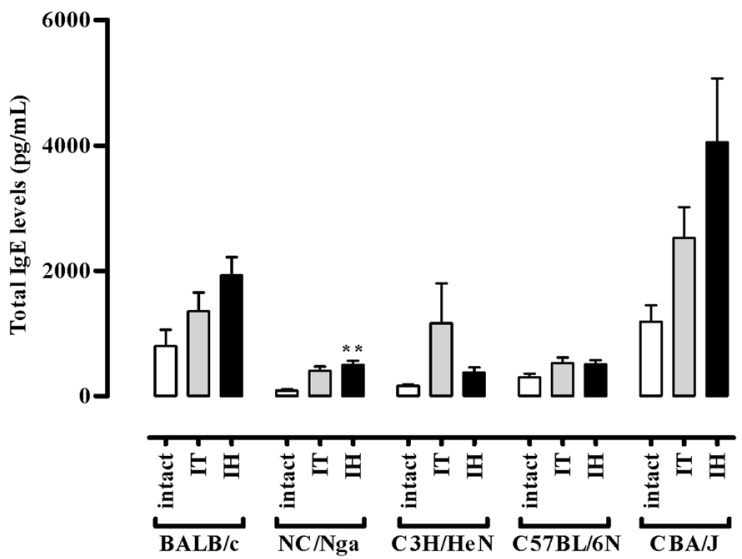

b)

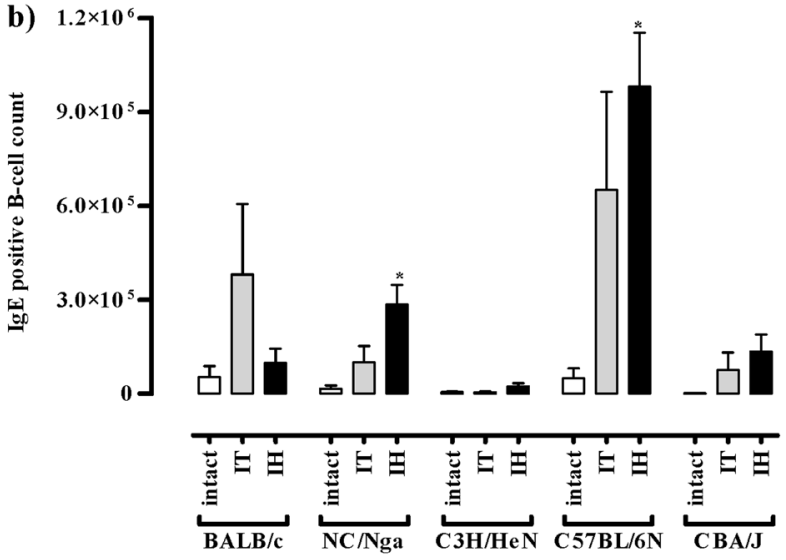

Fig. 3. (a) Total serum IgE levels (pg/ml; mean $\pm 1 \mathrm{SD} ; \mathrm{n}=5$ per group) and (b) IgE-positive B-cell counts (mean $\pm 1 \mathrm{SD}$; $\mathrm{n}=5$ per group) in mice with no treatment (intact), dermal sensitization followed by intratracheal challenge with GA (IT), or dermal sensitization followed by inhaled challenge with GA (IH). Values significantly different from that of the intact group are indicated by asterisks $\left(^{*}, P<0.05\right.$; **, $P<0.01 ; t$-test).

a known high responder of Th2-mediated immunoreactions [27]. In the current study, we evaluated and compared the airway allergic responses of the BALB/c, NC/ $\mathrm{Nga}, \mathrm{C} 3 \mathrm{H} / \mathrm{HeN}, \mathrm{C} 57 \mathrm{BL} / 6 \mathrm{~N}$, and CBA/J strains of mice in our model system using chemical respiratory allergen glutaraldehyde (GA). These strains are all used frequently in studies of inflammation, respiratory allergens, and allergy. C57BL/6N strain mice are Th1 high responders and have been used in several inflammation [36, 39] and respiratory allergy [29] models. Established as an inbred strain in 1995, NC/Nga mice originated from Japanese fancy mice [24] and have been useful in models of human atopic dermatitis and allergic airway inflammation [16]. In addition, NC/Nga mice demon- 
a)
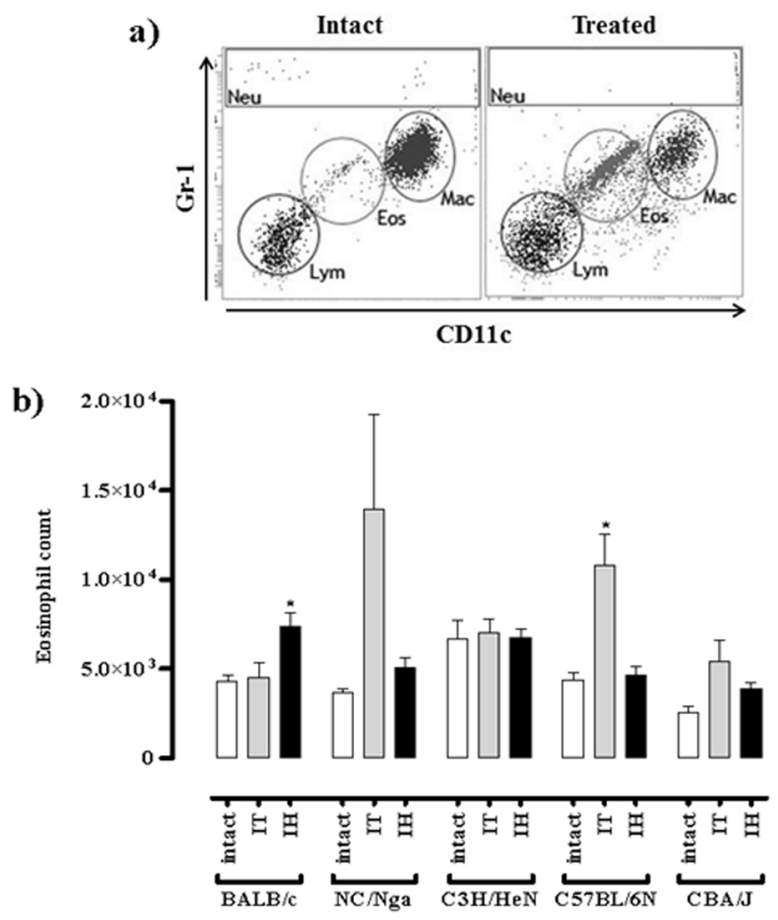

c)

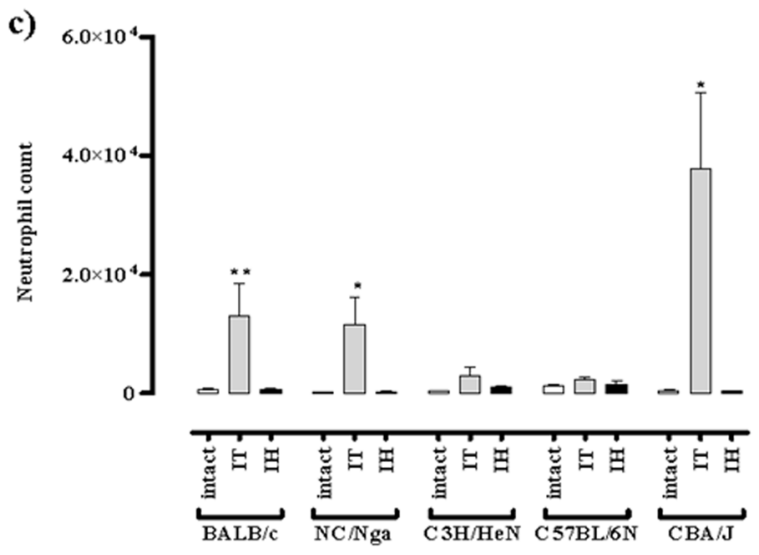

Fig. 4. Differential cell counts (mean $\pm 1 \mathrm{SD} ; \mathrm{n}=5$ per group) and in BALF of mice with no treatment (intact), dermal sensitization followed by intratracheal challenge with GA (IT), or dermal sensitization followed by inhaled challenge with GA (IH). (a) Representative dot plots showing the gating strategy used to identify different cell types in BALF. (b) Eosinophil and (c) neutrophil counts. Values significantly different from that of the intact group are indicated by asterisks $(*, P<0.05 ; * *, P<0.01 ; t$-test).

strated particularly massive and prolonged allergic responses, such as eosinophilic inflammation and IgE production, in our previous study [30]. We included $\mathrm{CBA} / \mathrm{J}$ mice in the current study because this strain has often been used in LLNAs as a method for identifying potential skin-sensitizing substances [20,31]. C3H/HeN a)

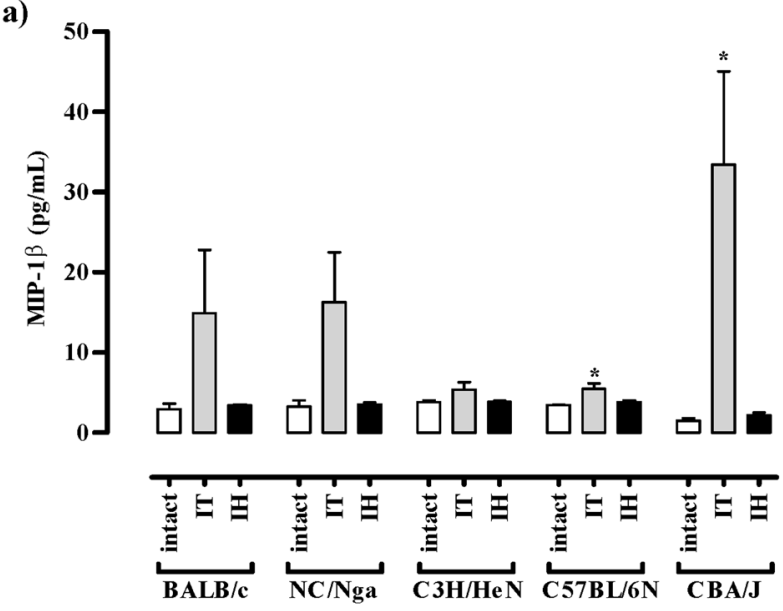

b)

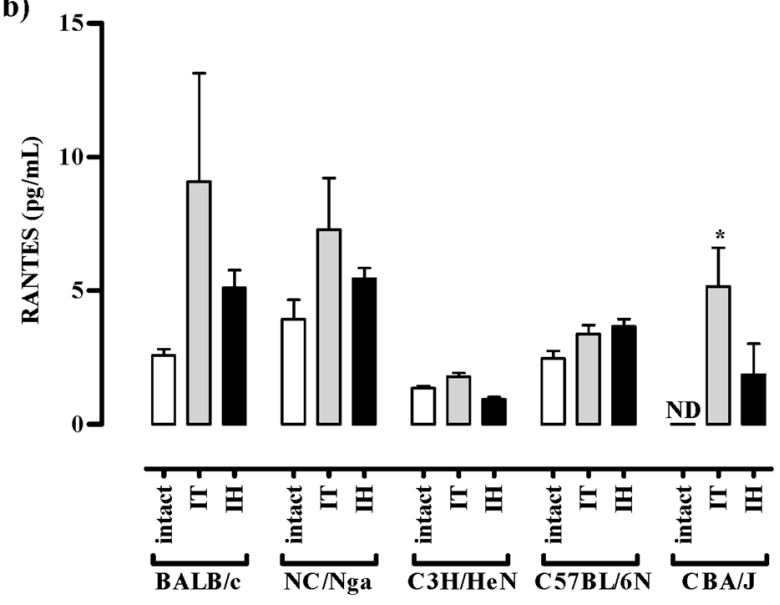

Fig. 5. Differential chemokine levels (pg/ml; mean $\pm 1 \mathrm{SD} ; \mathrm{n}=5$ per group) in BALF of mice with no treatment (intact), dermal sensitization followed by intratracheal challenge with GA (IT), or dermal sensitization followed by inhaled challenge with GA (IH). (a) MIP-1ßand (b) RANTES concentrations. Values significantly different from that of the intact group are indicated by asterisks $(*, P<0.05$; **, $P<0.01 ; t$-test).

mice are a common strain in diverse fields of research including allergy [43]. In the current study, we considered $\mathrm{C} 3 \mathrm{H} / \mathrm{HeN}$ mice to represent the overall moderate responder among the strains we evaluated.

We first confirmed the concentration of GA that yielded a positive response (i.e., EC3 value $\geq 3$ ) in the LLNA. This test assesses the potential of chemicals to cause a primary T-lymphocyte proliferative response after topical application of the test chemical to the skin of mice [9]. Because the LLNA involves dermal application, strictly speaking, it is appropriate only for assessing the risk of allergic contact dermatitis. However, Vanoirbeek 
a)

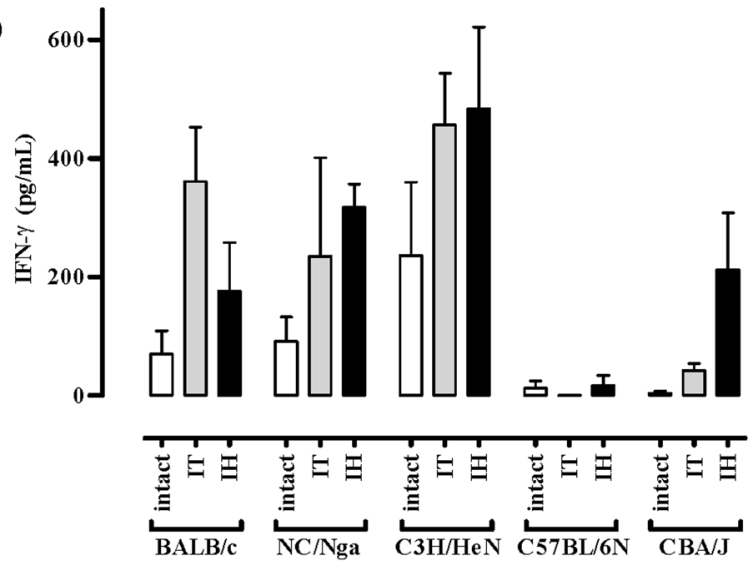

c)

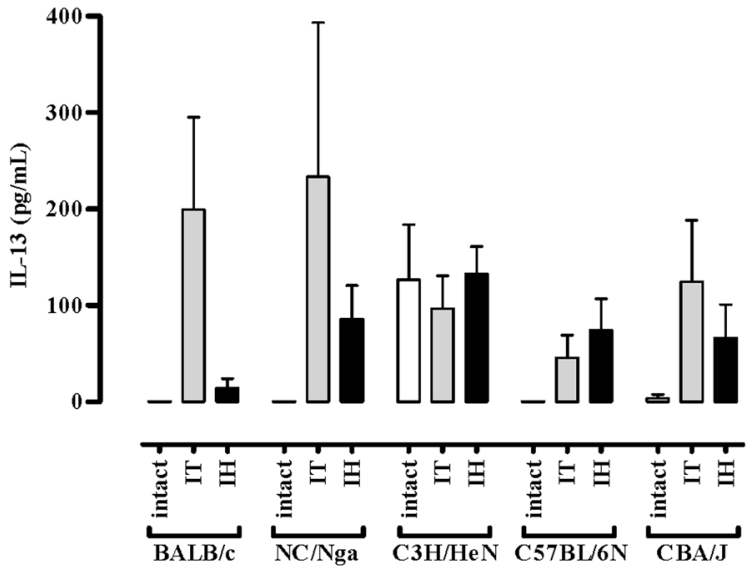

b)

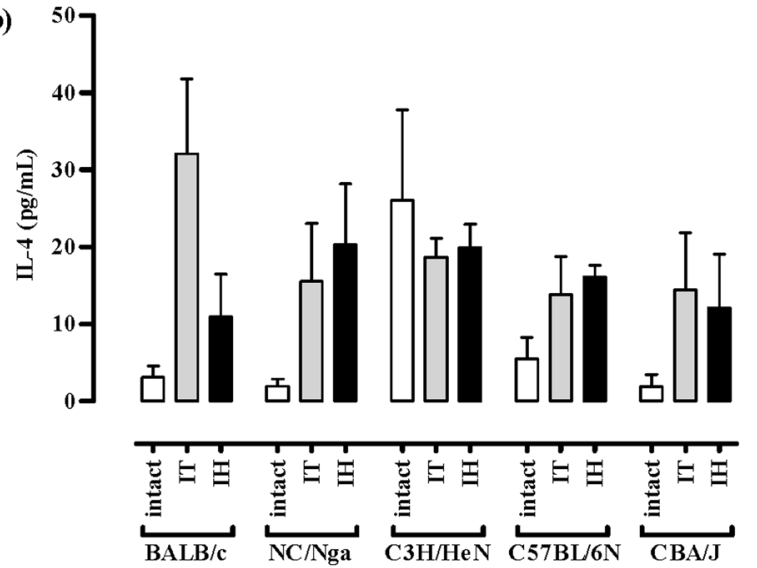

d)

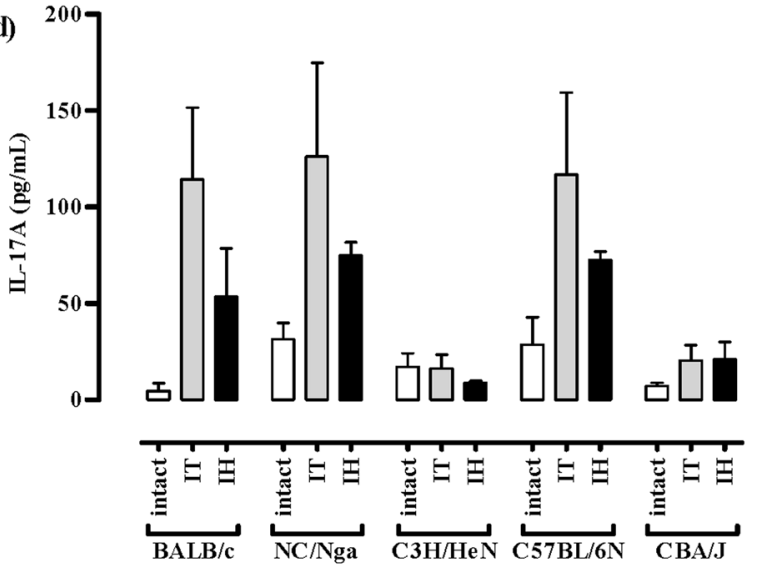

Fig. 6. Cytokine production in hilar LN cells. Designations of treatments are as in Fig. 2. The levels of (a) IFNr, (b) IL-4, (c) IL-13, and (d) IL-17A are expressed as mean $\pm \mathrm{SD}$ (pg/ml; $\mathrm{n}=5$ per group).

et al. [41] demonstrated that this test could be used to estimate the "generic" sensitizing ability of chemicals. For the current study, we therefore adopted a sensitization dose of $0.5 \%$ GA which was equivalent to the EC3 value and a challenge dose of $0.25 \%$ GA which was half of the challenge dose. This challenge dose failed to induce a proliferative response after a single dose but effectively increased the population of LN cells after multiple doses.

To achieve our goal of identifying the optimal mouse strain(s) to use in our model, we focused on several immune parameters. Among them, IgE antibody plays an important role in the development of respiratory allergy and can be used as a marker of several chemical-induced allergies [21]. In addition, in the development of the allergic response, activated B-cells can act as antigenpresenting cells for helper T-cells, resulting in hyperproduction of $\operatorname{IgE}[14,17]$. To evaluate the IgE reactions after sensitization to GA, we measured total $\mathrm{IgE}$ in serum and the number of IgE-positive B-cells in LNs. According to our results, serum IgE levels and IgE-positive B-cells tended to be increased in the GA-treated groups as compared with the comtrol group of all strains. Furthermore the particularly strong increases in the serum IgE concentrations of the IH NC/Nga mice and the markedly elevated IgE-positive B-cell counts in the IH challenge group of the $\mathrm{NC} / \mathrm{Nga}$ mice suggest their likely high susceptibility to respiratory allergy. These upregulations in the $\mathrm{NC} / \mathrm{Nga}$ strains of mice imply that they are particularly suitable for use in our model system for identifying and evaluating environmental chemical-related respiratory allergens. In contrast, B-cell counts were markedy increased in the IH challenge group of the C57BL/6N mice, but serum IgE concentrations of the treated $\mathrm{C} 57 \mathrm{BL} / 5 \mathrm{~N}$ groups were comparable to the control group. Although $\mathrm{CBA} / \mathrm{J}$ treated groups were in- 
Table 1. Allergic responses among inbred mouce strains

\begin{tabular}{lcccccc}
\hline & & $\mathrm{BALB} / \mathrm{c}$ & $\mathrm{NC} / \mathrm{Nga}$ & $\mathrm{C} 3 \mathrm{H} / \mathrm{HeN}$ & $\mathrm{C} 57 \mathrm{BL} / 6 \mathrm{~N}$ & $\mathrm{CBA} / \mathrm{J}$ \\
\hline IgE & IT & + & ++ & + & + & + \\
\multirow{2}{*}{ IgE positive B-cell } & IH & ++ & ++ & + & + & + \\
\multirow{2}{*}{ eosinophil } & IT & + & + & - & + & + \\
& IT & - & ++ & - & ++ & + \\
neutrophil & IH & ++ & + & - & ++ & ++ \\
\multirow{2}{*}{ chemokine } & IT & + & + & ++ & ++ & ++ \\
\multirow{2}{*}{ cytokine } & IH & - & - & - & - & - \\
& IT & ++ & + & - & ++ & + \\
& IH & + & + & - & ++ & - \\
& IT & ++ & + & - & + & ++ \\
$-:$ & IH & + & ++ & - & ++ & + \\
\hline
\end{tabular}

-: comparable to the intact group. +: increase compared with the intact group. ++ : significantly increase compared with the intact group.

creased to serum IgE level, B-cell counts were comparable to the control group. It is showed that $\operatorname{IgE}$ prosductivity of B-cell in $\mathrm{C} 57 \mathrm{BL} / 6 \mathrm{~N}$ was lower than other strain, and $\mathrm{IgE}$ prosductivity of B-cell in $\mathrm{CBA} / \mathrm{J}$ was high. Thus, it is suggested that IgE productivity of B-cell differ with mice strains.

Respiratory allergy is a chronic inflammatory disease of the airways that is characterized by reversible airway observation, airway hyperreactivity, and remodeling of airways. Infiltration of eosinophils into lung is a fundamental trait of the inflammatory response in respiratory allergy and may be important in the pathogenesis of this disease [23, 26, 28, 32]. In addition, eosinophils can release chemokines (MIP-1, RANTES, etc.) as allergyrelated chemical mediators. Neutrophils are also involved in allergic inflammatory reactions [10]. We therefore used flow cytometry to analyze the eosinophil and neutrophil counts and the levels of allergy-related chemokines (MIP-1 $\beta$ and RANTES) in BALF. According to our results, these parameters tended to be increased in the IT challenged groups of BALB/c, NC/Nga, and $\mathrm{CBA} / \mathrm{J}$ mice and the IH BALB/c mice. These upregulations in the BALF of BALB/c and NC/Nga mice appeared particularly well correlated with their $\operatorname{IgE}$ reactions.

Like IgE and BALF reactions, T-lymphocytes play a pivotal role in the development of respiratory allergic diseases. The mechanism of chemical-induced respiratory allergy is dependent on Th2-type cytokines [1]. $\mathrm{CD}^{+} \mathrm{T}$-cells infiltrate the lung lumen and express a $\mathrm{T}$ helper type 2 (Th2) pattern of cytokines [1, 43]. Cytokines secreted by these cells, including IL-4 and -13 , appear to function in concert with chemokines and other mediators to recruit and activate the eosinophils of the allergic inflammatory response [19]. In our current study, BALB/c, NC/Nga, C57/BL6N, and CBA/J mice showed increased LN production of Th2 (IL-4, -13) and Th1 (IFN- $\gamma$ ) cytokines compared with control levels. Th1 cytokines are associated with allergic contact dermatitis [20] and contribute to allergic airway inflammation [7]. Th17 cells recently have been shown to produce IL-17A, which is considered to be a pivotal proinflammatory molecule in respiratory allergy [35]. In our study, all strains except $\mathrm{C} 3 \mathrm{H} / \mathrm{HeN}$ showed increased production of IL-17A by LN cells after challenge, and these increases were particularly pronounced in the IH groups of $\mathrm{NC} / \mathrm{Nga}$ and $\mathrm{C} 57 \mathrm{BL} / 6 \mathrm{~N}$ mice. As described earlier, the upregulations that we noted in the LNs of BALB/c and $\mathrm{NC} / \mathrm{Nga}$ may correlate with the IgE and BALF reactions observed. In the control group of $\mathrm{C} 3 \mathrm{H} / \mathrm{HeN}$ mice, these cytokine levels were notably high as compared with those of other strains and were comparable to the treated groups of $\mathrm{C} 3 \mathrm{H} / \mathrm{HeN}$ mice. According to the mentioned above, $\mathrm{C} 3 \mathrm{H} / \mathrm{HeN}$ mice might be inappropriate for use in our model system for identifying and evaluating environmental chemical-related respiratory allergens because their high responder of cytokine productions.

Overall, the results support the notion that allergic responses differ among exposure routes and strains of inbred mice (Table 1). Dermal sensitization and intratracheal challenge groups showed high susceptibility to respiratory allergic inflammation. Although not the actual route for the introduction of respiratory allergens, intratracheal administration is one of the topical and directly administration of lung and pulmonary inflammation more directly than does inhalation exposure, 
perhaps even causing excessive inflammation [6]. In comparison, IgE and cytokine levels, which are known to be involved in the development of respiratory allergy, were increased after our inhalation challenge, which more closely approximates the actual exposure route than does intratracheal administration. Therefore we suggest that these responses that were induced by inhalation exposure according to our protocol correspond to real environmental data.

The BALB/c, NC/Nga, C57BL/6N, and CBA/J treatment groups all showed increased allergic airway inflammation. In addition, the $\mathrm{BALB} / \mathrm{c}$ and $\mathrm{NC} / \mathrm{Nga}$ mice showed fairly uniform increases in all analyses and smaller dispersion than did the other strains. Although $\mathrm{C} 3 \mathrm{H} / \mathrm{HeN}$ mice demonstrated markedly increased total IgE levels in serum, the levels of cytokine were comparable to those of the control groups. Therefore, we propose that the $\mathrm{BALB} / \mathrm{c}$ and $\mathrm{NC} / \mathrm{Nga}$ mouse strains are likely to be particularly useful in developing an effective method for identifying and evaluating environmental respiratory allergens. Our future efforts will focus on further refining our model system in these two mouse strains.

\section{Acknowledgments}

We thank Dr. Y. Takizawa of the Institute of Environmental Toxicology (Uchimoriya-machi 4321, Joso-shi, Ibaraki 303-0043, Japan) for their technical assistance.

\section{References}

1. Andersson, M., Greff, L., Svensson, C., and Persson, C.G.A. 2000. Allergic and non-allergic rhinitis. In: Busse, W.W., Holgate, S.T. (Eds), Asthma and Rhinitis, vol.1, 2nd ed. Blackwell Science, Oxford, pp.232-244.

2. Ballantyne, B. and Jordan, S.L. 2001. Toxicological, medical and industrial hygiene aspects of glutaraldehyde with particular reference to its biocidal use in cold sterilization procedures. J. Appl. Toxicol. 21: 131-151. [Medline] [CrossRef]

3. Ban, M. and Hettich, D. 2005. Effect of Th2 cytokine antagonist treatments on chemical-induced allergic response in mice. J. Appl. Toxicol. 25: 239-247. [Medline] [CrossRef]

4. Ban, M., Morel, G., Langonné, I., Huguet, N., Pépin, E., and Binet, S. 2006. TDI can induce respiratory allergy with Th2dominated response in mice. Toxicology 218: 39-47. [Medline] [CrossRef]

5. Basketter, D.A., Lea, L.J., Dickens, A., Briggs, D., Pate, I., Dearman, R.J., and Kimber, I. 1999. A comparison of statistical approaches to the derivation of EC3 values from local lymph node assay dose responses. J. Appl. Toxicol. 19:
261-266. [Medline] [CrossRef]

6. Brain, J.D., Knudson, D.E., Sorokin, S.P., and Davis, M.A. 1976. Pulmonary distribution of particles given by intratracheal instillation or by aerosol inhalation. Environ. Res. 11: 13-33. [Medline] [CrossRef]

7. Brightling, C., Berry, M., and Amrani, Y. 2008. Targeting TNF-alpha: a novel therapeutic approach for asthma. $J$. Allergy Clin. Immunol. 121: 5-10, quiz 11-12. [Medline] [CrossRef]

8. Brown, M.M. and Jason, L.A. 2007. Functioning in individuals with chronic fatigue syndrome: increased impairment with co-occurring multiple chemical sensitivity and fibromyalgia. Dyn. Med. 6: 6. [Medline] [CrossRef]

9. Dearman, R.J., Basketter, D.A., and Kimber, I. 1999. Local lymph node assay: use in hazard and risk assessment. $J$. Appl. Toxicol. 19: 299-306. [Medline] [CrossRef]

10. Fujisawa, T., Kephart, G.M., Gray, B.H., and Gleich, G.J. 1990. The neutrophil and chronic allergic inflammation. Immunochemical localization of neutrophil elastase. Am. Rev. Respir. Dis. 141: 689-697. [Medline] [CrossRef]

11. Fukuyama, T., Tajima, Y., Ueda, H., Hayashi, K., Shutoh, Y., Saito, T.R., Harada, T., and Kosaka, T. 2009. Investigation of the chemical-induced selective type II (T(H)2) allergic response in mice: effect of the length of the sensitizing phase. J. Immunotoxicol. 6: 75-83. [Medline] [CrossRef]

12. Fukuyama, T., Ueda, H., Hayashi, K., Tajima, Y., Shuto, Y., Saito, T.R., Harada, T., and Kosaka, T. 2008. Use of long term dermal sensitization followed by intratracheal challenge method to identify low-dose chemical-induced respiratory allergic responses in mice. Toxicol. Lett. 181: 163-170. [Medline] [CrossRef]

13. Gavett, S.H., Haykal-Coates, N., Copeland, L.B., Heinrich, J., and Gilmour, M.I. 2003. Metal composition of ambient PM2.5 influences severity of allergic airways disease in mice. Environ. Health Perspect. 111: 1471-1477. [Medline]

14. Goutet, M., Pépin, E., Langonné, I., Huguet, N., and Ban, M. 2005. Identification of contact and respiratory sensitizers using flow cytometry. Toxicol. Appl. Pharmacol. 205: 259-270. [Medline]

15. Howarth, P.H. 1998. Is allergy increasing? — early life influences. Clin. Exp. Allergy 28: 2-7. [Medline] [CrossRef]

16. Iwasaki, T., Tanaka, A., Matsuda, H., and Onuma, M. 2001. Atopic NC/Nga mice as a model for allergic asthma: cytokine profiles and eosinophil productivity of bone marrow. $J$. Vet. Med. Sci. 63: 471-474. [Medline] [CrossRef]

17. Janeway, C.A., Travers, P., Walport, M., and Shlomchik, M.J., editors. 2004. Immunobiology, 6th ed. Grand Science, New York.

18. Janssen, N.A., Brunekreef, B., van Vliet, P., Aarts, F., Meliefste, K., Harssema, H., and Fischer, P. 2003. The relationship between air pollution from heavy traffic and allergic sensitization, bronchial hyperresponsiveness, and respiratory symptoms in Dutch schoolchildren. Environ. Health Perspect. 111: 1512-1518. [Medline]

19. Jeebhay, M.F. and Quirce, S. 2007. Occupational asthma in the developing and industrialised world: a review. Int. J. Tuberc. Lung Dis. 11: 122-133. [Medline]

20. Kimber, I. and Weisenberger, C. 1989. A murine local lymph 
node assay for the identification of contact allergens. Assay development and results of an initial validation study. Arch. Toxicol. 63: 274-282. [Medline] [CrossRef]

21. Kimber, I. and Dearman, R.J. 2002. Chemical respiratory allergy: role of $\mathrm{IgE}$ antibody and relevance of route of exposure. Toxicology 181-182: 311-315. [Medline] [CrossRef]

22. Kimber, I., Agius, R., Basketter, D.A., Corsini, E., Cullinan, P., Dearman, R.J., Gimenez-Arnau, E., Greenwell, L., Hartung, T., Kuper, F., Maestrelli, P., Roggen, E., Rovida, C., and European Centre for the Validation of Alternative Methods 2007. Chemical respiratory allergy: opportunities for hazard identification and characterisation. The report and recommendations of ECVAM workshop 60. Altern. Lab. Anim. 35: 243-265. [Medline]

23. Kimber, I., Basketter, D.A., Gerberick, G.F., Ryan, C.A., and Dearman, R.J. 2011. Chemical allergy: translating biology into hazard characterization. Toxicol. Sci. 120: S238-S268. [Medline] [CrossRef]

24. Kondo, K., Nagami, T., and Teramoto, S.1969. Differences in haematopoietoc death among inbred strains of mice. In Bond, P. V. and Sugahara, T., eds, Comparative Cellular and Species Radiosensitivity, p. 20. Igakushoin, Tokyo.

25. Kreutzer, R., Neutra, R.R., and Lashuay, N. 1999. Prevalence of people reporting sensitivities to chemicals in a population-based survey. Am. J. Epidemiol. 150: 1-12. [Medline] [CrossRef]

26. Kroegel, C., Liu, M.C., Hubbard, W.C., Lichtenstein, L.M., and Bochner, B.S. 1994. Blood and bronchoalveolar eosinophils in allergic subjects after segmental antigen challenge: surface phenotype, density heterogeneity, and prostanoid production. J. Allergy Clin. Immunol. 93: 725-734. [Medline] [CrossRef]

27. Lin, J.Y., Chen, M.L., Chiang, B.L., and Lin, B.F. 2006. Ganoderma tsugae supplementation alleviates bronchoalveolar inflammation in an airway sensitization and challenge mouse model. Int. Immunopharmacol. 6: 241-251. [Medline] [CrossRef]

28. Lötvall, J., Inman, M., and O'Byrne, P. 1998. Measurement of airway hyperresponsiveness: new considerations. Thorax 53: 419-424. [Medline] [CrossRef]

29. Morokata, T., Ishikawa, J., and Yamada, T. 2000. Antigen dose defines $\mathrm{T}$ helper 1 and $\mathrm{T}$ helper 2 responses in the lungs of $\mathrm{C} 57 \mathrm{BL} / 6$ and BALB/c mice independently of splenic responses. Immunol. Lett. 72: 119-126. [Medline] [CrossRef]

30. Nishino, R., Fukuyama, T., Tajima, Y., Miyashita, L., Watanabe, Y., Ueda, H., and Kosaka, T. 2013. Prior oral exposure to environmental immunosuppressive chemicals methoxychlor, parathion, or piperonyl butoxide aggravates allergic airway inflammation in NC/Nga mice. Toxicology 309: 1-8. [Medline] [CrossRef]

31. Organization for Economic Co-operation and Development. 2010. OECD test guideline for the testing of chemicals. Skin Sensitization: Local Lymph Node Assay. 2010. OECD Test Guideline No. 429. http://www.oecd-ilibrary.org/environment/test-no-429-skin-sensitisation_9789264071100-en.
32. Pearce, N., Aït-Khaled, N., Beasley, R., Mallol, J., Keil, U., Mitchell, E., Robertson, C., and ISAAC Phase Three Study Group 2007. Worldwide trends in the prevalence of asthma symptoms: phase III of the International Study of Asthma and Allergies in Childhood (ISAAC). Thorax 62: 758-766. [Medline] [CrossRef]

33. Quirce, S., Gómez, M., Bombín, C., and Sastre, J. 1999. Glutaraldehyde-induced asthma. Allergy 54: 1121-1122. [Medline] [CrossRef]

34. Rothen-Rutishauser, B.M., Kiama, S.G., and Gehr, P. 2005. A three-dimensional cellular model of the human respiratory tract to study the interaction with particles. Am. J. Respir. Cell Mol. Biol. 32: 281-289. [Medline] [CrossRef]

35. Song, C., Luo, L., Lei, Z., Li, B., Liang, Z., Liu, G., Li, D., Zhang, G., Huang, B., and Feng, Z.H. 2008. IL-17-producing alveolar macrophages mediate allergic lung inflammation related to asthma. J. Immunol. 181: 6117-6124. [Medline] [CrossRef]

36. Spergel, J.M., Mizoguchi, E., Oettgen, H., Bhan, A.K., and Geha, R.S. 1999. Roles of TH1 and TH2 cytokines in a murine model of allergic dermatitis. J. Clin. Invest. 103: 11031111. [Medline] [CrossRef]

37. Takigawa, T. and Endo, Y. 2006. Effects of glutaraldehyde exposure on human health. J. Occup. Health 48: 75-87. [Medline] [CrossRef]

38. United Nations (2011): Chapter 3.4, Respiratory or skin sensitization. In Globally Harmonized System of Classification and Labeling of Chemicals (GHS) fourth revised edition. New York and Geneva, United Nations.

39. Van Hove, C.L., Maes, T., Cataldo, D.D., Guéders, M.M., Palmans, E., Joos, G.F., and Tournoy, K.G. 2009. Comparison of acute inflammatory and chronic structural asthma-like responses between C57BL/6 and BALB/c mice. Int. Arch. Allergy Immunol. 149: 195-207. [Medline] [CrossRef]

40. van Triel, J.J., van Bree, B.W., Roberts, D.W., Muijser, H., Duistermaat, E., Woutersen, R.A., and Kuper, C.F. 2011. The respiratory allergen glutaraldehyde in the local lymph node assay: sensitization by skin exposure, but not by inhalation. Toxicology 279: 115-122. [Medline] [CrossRef]

41. Vanoirbeek, J.A., Mandervelt, C., Cunningham, A.R., Hoet, P.H., Xu, H., Vanhooren, H.M., and Nemery, B. 2003. Validity of methods to predict the respiratory sensitizing potential of chemicals: A study with a piperidinyl chlorotriazine derivative that caused an outbreak of occupational asthma. Toxicol. Sci. 76: 338-346. [Medline] [CrossRef]

42. Vyas, A., Pickering, C.A., Oldham, L.A., Francis, H.C., Fletcher, A.M., Merrett, T., and Niven, R.M. 2000. Survey of symptoms, respiratory function, and immunology and their relation to glutaraldehyde and other occupational exposures among endoscopy nursing staff. Occup. Environ. Med. 57: 752-759. [Medline] [CrossRef]

43. Whitehead, G.S., Walker, J.K., Berman, K.G., Foster, W.M., and Schwartz, D.A. 2003. Allergen-induced airway disease is mouse strain dependent. Am. J. Physiol. Lung Cell. Mol. Physiol. 285: L32-L42. [Medline] 